\title{
Ex vivo transcriptional profiling of human pancreatic islets following chronic exposure to monounsaturated fatty acids
}

\author{
George Bikopoulos, Aurelio da Silva Pimenta ${ }^{1}$, Simon C Lee $^{2}$, Jonathan R Lakey ${ }^{3}$, Sandy D Der, \\ Catherine B Chan ${ }^{4}$, Rolando Bacis Ceddia ${ }^{1}$, Michael B Wheeler ${ }^{2}$ and Maria Rozakis-Adcock
}

Department of Laboratory Medicine and Pathobiology, 1 King's College Circle, University of Toronto, Toronto, Canada M5S $1 \mathrm{~A} 8$

${ }^{1}$ School of Kinesiology and Health Science, York University, Ontario, Canada M3J1 P3

${ }^{2}$ Department of Physiology, 1 King's College Circle, University of Toronto, Toronto, Canada M5S 1A8

${ }^{3}$ Clinical Islet Transplant Program, Department of Transplant Services, University of Alberta Hospital, Edmonton, Alberta, Canada T6G 2C8

${ }^{4}$ Department of Agricultural, Food and Nutritional Science, University of Alberta, Edmonton, Alberta, Canada T6G 2E1

(Correspondence should be addressed to M B Wheeler; Email: michael.wheeler@utoronto.ca; M Rozakis-Adcock; Email: maria.rozakis@utoronto.ca)

\begin{abstract}
The aim of this study was to assess the effects of chronic free fatty acid (FFA) exposure on gene expression and the functional state of human pancreatic islets. Chronic exposure of islets to oleate $(\mathrm{OA})$ resulted in a significant reduction in glucose-stimulated insulin secretion (GSIS) compared with control $(466 \pm 82$ vs $234 \pm 57 \mathrm{ng} / \mu \mathrm{g}$ DNA, $P<0 \cdot 05)$. OA treatment also led to reduction in total insulin content of the islets $(17609 \pm 3816 \mathrm{vs}$ $10599 \pm 3876 \mathrm{ng}$ insulin/ $\mu \mathrm{g}$ DNA) and to an increase in the rate of reactive oxygen species (ROS) generation. Interestingly, the suppressive effects of OA on biosynthesis and secretion of insulin were accompanied by alteration in the expression of 40 genes, as determined by microarray analysis and subsequent qPCR validation. The majority of genes regulated by OA encoded metabolic enzymes. The expression of enzymes
\end{abstract}

involved in oxidative defense was elevated, indicating a link between ROS generation and antioxidant defense activation. Additionally, pretreatment of human islets with OA led to a significant increase $(30 \%)$ in the rate of oxidation of this fatty acid and to a significant decrease $(75 \%)$ in glucose oxidation. Importantly, individual analysis of gene clusters from the islets of all donors revealed the induction of genes involved in inflammation and immunity, which provides further evidence that FFA are risk factors for the development of type 2 diabetes. In summary, our data indicate that chronic exposure of human islets to FFA activates inflammatory and metabolic pathways that lead to oxidative stress, reduced $\beta$-cell insulin content, and inhibition of GSIS.

Journal of Endocrinology (2008) 196, 455-464

\section{Introduction}

Type 2 diabetes (T2D) is a multifactorial disease and its etiology is attributed to a combination of genetic and environmental factors (Haslam \& James 2005). Defects in $\beta$-cell function are critical in the development of both T1D and T2D. The prevalence of obesity in modern societies has increased dramatically over the past few years and has reached epidemic proportions. Obesity is closely related to insulin resistance and hyperinsulinemia and the very frequent combination of obesity and T2D is characterized as 'diabesity' (Koulouridis 2004). A multitude of factors contribute to the pathogenesis of T2D including inflammatory cytokines, increased concentrations of free fatty acids (FFA), adipokines, impaired mitochondrial function through defects in mitochondrial lipid oxidation, endoplasmic reticulum (ER) stress, and chronic hyperglycemia (referred to as glucotoxicity; Stumvoll et al. 2005).

Since T2D is a heterogeneous clinical entity, determining its causes and consequences is a challenging issue. High-throughput methods, such as microarrays, allow the screening of a large number of genes in a relatively short period of time (Stoughton 2005). To date, there are no published studies that have used microarrays to identify candidate genes and relevant metabolic and signaling pathways regulated by FFA in human pancreatic islets. This is primarily due to the scarcity of human tissue for research purposes (Haber et al. 2003, 2006, Newsholme et al. 2007b). Alterations in patterns of expression of multiple genes can offer new insights into regulatory mechanisms, biochemical pathways, and potentially aid in the development of unique therapeutic drug targets.

A plethora of studies has indicated that chronic exposure of $\beta$ cells to elevated levels of FFA is accompanied by the loss of glucose-stimulated insulin secretion (GSIS) and a decrease in total insulin content (Paolisso et al. 1995, Mason et al. 1999, Lupi et al. 2002a, Oprescu et al. 2007). Additionally, the consensus from numerous studies indicates that monounsaturated as well as the majority of polyunsaturated fatty acids are well tolerated as opposed to long-chain saturated fatty acids that are the most toxic to $\beta$ cells (Haber et al. 2003, 2006, 
Newsholme et al. 2007b). Oleate (OA) has been shown to induce defects in GSIS in numerous pancreatic $\beta$-cell lines as well as rodent and human islets (Haber et al. 2006). However, its toxicity is minimal since no significant induction of apoptosis in $\beta$ cells with this fatty acid has been reported (Newsholme et al. 2007b). Thus, for the purpose of our study, we used OA as the FFA of choice in order to eliminate possible toxic effects on pancreatic islets. Here, we used oligonucleotide microarrays and quantitative real-time PCR in order to examine the role of chronic FFA exposure in human islets on a genome-wide scale. In addition, we examined various pathways involved in $\beta$-cell function/ physiology. Importantly, individual analysis of gene clusters from the islets of all donors revealed the induction of genes involved in reactive oxygen species (ROS) activity, inflammation, and immunity. This provides evidence that chronic exposure of human islets to FFA activates inflammatory and metabolic pathways that lead to oxidative stress, reduced $\beta$-cell insulin content, and inhibition of GSIS.

\section{Materials and Methods}

\section{Fatty acid preparation}

OA bound to fatty acid-free BSA was prepared by stirring $4 \mathrm{mmol} / \mathrm{l}$ OA with $5 \%$ (wt/vol) BSA in Krebs-Ringer HEPES buffer (KRBH) for $30 \mathrm{~min}$ at $50{ }^{\circ} \mathrm{C}$. Quantitative determination of FFA in the resulting solution was achieved by the use of the NEFA $C$ test kit assay (VWR International, Canada).

\section{Human islet isolation and culture}

Human islets were obtained from the Clinical Transplantation Laboratory at the University of Alberta from non-diabetic human cadavers. Human islets were isolated following the Edmonton Protocol (O'Gorman et al. 2005) and cultured in RPMI 1640 medium supplemented with $5.5 \mathrm{mmol} / 1$ glucose, $10 \%$ fetal bovine serum, $25 \mathrm{mmol} / 1$ HEPES, $2 \mathrm{mmol} / 1$ L-glutamine, $100 \mathrm{Units} / \mathrm{ml}$ penicillin, and $100 \mu \mathrm{g} / \mathrm{ml}$ streptomycin, in a $37^{\circ} \mathrm{C}$ humidified chamber. Human islets were incubated in RPMI 1640 containing $5.5 \mathrm{mmol} / \mathrm{l}$ glucose and treated for $48 \mathrm{~h}$ with either $0.5 \%$ (wt/vol) BSA or $0.4 \mathrm{mM}$ OA in BSA. Human islet donor information is summarized in Supplemental Table 1, which can be viewed online at http://joe.endocrinology-journals. org/content/vol196/issue3/.

\section{Insulin secretion experiments and insulin content determination}

Human islets (20 islets/well) were preincubated for two sequential periods of $30 \mathrm{~min}$ in $\mathrm{KRBH}$ buffer (components $(128.8 \mathrm{mmol} / 1 \mathrm{NaCl}, 4.8 \mathrm{mmol} / 1 \mathrm{KCl}, \quad 1.2 \mathrm{mmol} / 1$ $\mathrm{KH}_{2} \mathrm{PO}_{4}, \quad 1.2 \mathrm{mmol} / 1 \quad \mathrm{MgSO}_{4}, \quad 2.5 \mathrm{mmol} / 1 \quad \mathrm{CaCl}_{2}$, $5 \mathrm{mmol} / \mathrm{l} \mathrm{NaHCO}_{3}$, and $10 \mathrm{mmol} / \mathrm{l} \mathrm{HEPES}$ ) containing
$2 \cdot 8 \mathrm{mmol} / 1$ glucose and $0 \cdot 1 \%$ BSA in a $37^{\circ} \mathrm{C}$ humidified air incubator. The islets were incubated in $\mathrm{KRBH}$ buffer containing low $(2.8 \mathrm{mmol} / \mathrm{l})$ or high $(16.7 \mathrm{mmol} / \mathrm{l})$ glucose concentrations for $1 \mathrm{~h}$. Insulin in the supernatant was determined using an RIA kit (Linco Research Inc., St Charles, MO, USA). Insulin secretion measurements were normalized to total DNA content in the sample. The total cellular insulin (50 islets/well) content was extracted by sonication in buffer containing 75\% ethanol/1.5\% (vol/vol) $\mathrm{HCl}$ to ensure complete cellular lysis. The content was assessed by means of RIA as described previously (Wang et al. 2004). The DNA content of the human islets was measured from the ethanol/ $\mathrm{HCl}$ solution using a spectrophotometer.

\section{Intracellular ROS measurements}

Human islets were treated for $48 \mathrm{~h}$ with $0.4 \mathrm{mmol} / \mathrm{lOA}$ and incubated in $\mathrm{KRBH}$ buffer containing $5.5 \mathrm{mmol} / 1$ glucose, $0.4 \mathrm{mmol} / \mathrm{l} \mathrm{OA}$, and $10 \mu \mathrm{mol} / 1 \mathrm{DCFH}-\mathrm{DA}$ for $30 \mathrm{~min}$ at $37^{\circ} \mathrm{C}$. Fluorescence was recorded using an Olympus BX51W1 fluorescent microscope fitted with a $10 \times / 0 \cdot 30$ water immersion objective and cooled CCD camera equipped with a magnification changer (U-TVCAC, Olympus, Carsen Group Inc., Markham Canada). Measurements were performed at $480 \mathrm{~nm}$ excitation and $510 \mathrm{~nm}$ emission using a xenon lamp-based DeltaRam high-speed monochromator and video camera. The collected data were analyzed using the ImageMaster 3 software (Photon Technology International Inc., London, ON, Canada).

\section{$R N A$ extraction and gene expression profiling}

Total RNA was isolated from human islets (1000 islets) using TRIzol reagent (Invitrogen Inc.) and further purified by the RNeasy kit (Qiagen Inc.), according to the manufacturer's instructions. For each Affymetrix GeneChip, total RNA was prepared for hybridization and subsequently hybridized according to the recommendations from Affymetrix (Santa Clara, CA, USA). In all, islet preparations from five donors were processed using the U133A Affymetrix GeneChips. The GeneChips for microarray analysis were processed on two separate occasions.

Primer design, reverse transcription, and quantitative real-time PCR

Primers were designed using the software Primer Express (PE Applied Biosystems, Perkin-Elmer, Foster City, CA, USA). Each $10 \mu \mathrm{l}$ reaction mix consisted of $6 \mu \mathrm{l}$ real-time PCR master mix and $4 \mu$ template. Real-time PCR mix contained $1 \times$ PCR buffer, $3 \mathrm{mmol} / 1 \mathrm{MgCl}_{2}, 0.2 \mathrm{mmol} / \mathrm{l} \mathrm{dNT}$, $1 \mathrm{nmol} / 1$ forward and reverse primers, 1:50 dilution of ROX reference dye, 3:100 000 dilution of SYBR Green I, and 0.05 Units of Platinum Taq DNA polymerase. The real-time PCR was monitored and analyzed by the Sequence Detection 
System ver. 2.0 (PE Applied Biosystems, Perkin-Elmer). All genes were normalized to the control gene TATA box binding protein. Primer sequences are shown in Supplemental Table 2, which can be viewed online at http://joe.endocrinologyjournals.org/content/vol196/issue3/. All real-time PCR samples were processed simultaneously.

\section{Microarray data analysis}

The expression levels from microarrays along with the present/absent calls were calculated using GCOS ver. 1.2 (Affymetrix) with the statistical algorithm from MAS5. The setting used for GCOS analysis were the following: Alpha1: 0.05, Alpha2: 0.065, Tau: 0.015, Gamma1H: 0.0045, Gamma1L: 0.0045, Gamma2H: 0·006, Gamma2L: 0·006, Target: 500, NF: 1 . Genes chosen for the analysis were of present calls in all samples analyzed by GCOS. Furthermore, GCOS analysis included paired samples treated with fatty acids from each individual donor eliminating variables such as age and sex. Novel biological patterns in our microarray data were identified using L2L, a database consisting of lists of differentially expressed genes compiled from the published mammalian microarray studies. With the L2L database, we systematically compared our own list of differentially expressed genes with a database of lists of differentially expressed genes that were derived from the published microarray data, and identified common expression patterns.

\section{Glucose oxidation}

Glucose oxidation was determined by measuring the formation of ${ }^{14} \mathrm{CO}_{2}$ from $\left[\mathrm{U}_{-}{ }^{14} \mathrm{C}\right]$ glucose (Gaidhu et al. 2006). Groups of 200 islets were incubated in $2 \mathrm{ml}$ microtubes containing $500 \mu \mathrm{KRBH}(\mathrm{pH} 7 \cdot 4$ ) containing $0 \cdot 4 \mu \mathrm{Ci} / \mathrm{ml}$ $\mathrm{D}-\left[\mathrm{U}_{-}{ }^{14} \mathrm{C}\right]$ glucose plus non-radioactive glucose to a final concentration of either $2 \cdot 8$ or $16.7 \mathrm{mmol} / \mathrm{l}$. The buffer was gassed with $\mathrm{O}_{2}: \mathrm{CO}_{2}(95: 5 \%)$ for $30 \mathrm{~min}$ prior to the onset of the experiment. The microtubes containing islets were placed in standard $20 \mathrm{ml}$ scintillation vials. The scintillation vials were then capped airtight using rubber stoppers and gassed with $\mathrm{O}_{2}: \mathrm{CO}_{2}(95: 5 \%)$ for an additional $30 \mathrm{~s}$. Subsequently, the vials were shaken continuously at $37^{\circ} \mathrm{C}$ for $120 \mathrm{~min}$. The assay was terminated by injecting $200 \mu \mathrm{H}_{2} \mathrm{SO}_{4}(4 \mathrm{~mol} / \mathrm{l})$ into the microtube. ${ }^{14} \mathrm{CO}_{2}$ liberated from the incubation medium was captured by a subsequent injection of $500 \mu \mathrm{l}$ phenylethylamine-methanol (1:1) through the rubber stoppers into the scintillation vials. After $2 \mathrm{~h}$ at $37^{\circ} \mathrm{C}$ (to allow the liberated ${ }^{14} \mathrm{CO}_{2}$ to be trapped by phenylethylaminemethanol), the cap was removed, and $10 \mathrm{ml}$ scintillation fluid was added to each vial. Non-specific (NS) ${ }^{14} \mathrm{CO}_{2}$ produced was measured by incubating vials containing all buffers but lacking islets. The NS values were subtracted from all conditions. Radioactivity was measured in a liquid scintillation counter.

\section{$\mathrm{O} A$ oxidation}

OA oxidation was measured by the modification of a method described previously (Patane et al. 2000). In brief, groups of 200 islets were placed in $2 \mathrm{ml}$ microtubes containing $500 \mu \mathrm{KRBH}(\mathrm{pH} 7 \cdot 4)$ containing $0.4 \mu \mathrm{Ci} / \mathrm{ml}$ $\left[1-{ }^{14} \mathrm{C}\right] \mathrm{OA}$ and non-labeled OA (final concentration $20 \mu \mathrm{mol} / \mathrm{l}$ ), $5.5 \mathrm{mmol} / \mathrm{l}$ glucose, $2 \% \mathrm{BSA}$, and $0.8 \mathrm{mmol} / \mathrm{l}$ L-carnitine. The buffer was gassed with $\mathrm{O}_{2}: \mathrm{CO}_{2}(95: 5 \%)$ for $30 \mathrm{~min}$ prior to the onset of the experiment. The microtubes were placed in standard $20 \mathrm{ml}$ scintillation vials, gassed with $\mathrm{O}_{2}: \mathrm{CO}_{2}(95: 5 \%)$ for an additional $30 \mathrm{~s}$, and then capped airtight using rubber stoppers. The vials were then shaken continuously at $37^{\circ} \mathrm{C}$ for $120 \mathrm{~min}$. The assay was terminated by injecting $200 \mu \mathrm{H} \mathrm{H}_{2} \mathrm{SO}_{4}(4 \mathrm{~mol} / \mathrm{l})$ into the microtube. ${ }^{14} \mathrm{CO}_{2}$ liberated from the incubation medium was captured by a subsequent injection of $500 \mu$ phenylethylamine-methanol $(1: 1)$ through the rubber stoppers into the scintillation vials. After $2 \mathrm{~h}$ at $37^{\circ} \mathrm{C}$ (to allow the liberated ${ }^{14} \mathrm{CO}_{2}$ to be trapped by phenylethylaminemethanol), the cap was removed and $10 \mathrm{ml}$ scintillation fluid was added to each vial. Control (NS) incubation-lacking islets were run with each series. The NS values were subtracted from all conditions. Radioactivity was measured in a liquid scintillation counter.

\section{Statistical analysis}

Data are expressed as means 土s.E.M. Statistical analysis was performed using non-parametric tests. Insulin secretion data, insulin content, glucose/FFA oxidation, and ROS production measurements were analyzed using the Wilcoxon test. The real-time PCR data were analyzed using the Mann-Whitney $U$ test. Differences were deemed significant when $P<0 \cdot 05$.

\section{Results}

The effects of $\mathrm{OA}$ exposure on insulin secretion and total islet insulin content

A large body of evidence deriving from both in vitro and in vivo studies in rodent models suggests that FFA impair insulin secretion and additionally saturated fatty acids can impair insulin gene expression (Newsholme et al. 2007b). The exposure of human islets to $0.4 \mathrm{mmol} / 1 \mathrm{OA}$ for $48 \mathrm{~h}$ did not significantly change basal insulin secretion (BSA: $98 \cdot 3 \pm 12 \cdot 5$ versus $\mathrm{OA}: 134 \cdot 8 \pm 31 \cdot 7 \mathrm{ng}$ insulin/ $\mu \mathrm{g}$ DNA). However, OA exposure resulted in a significant reduction in insulin secretion induced by glucose $(466 \cdot 8 \pm 81 \cdot 7$ to $234 \cdot 8 \pm 57 \cdot 3$ ng insulin/ $\mu$ g DNA; Fig. 1A). Along with the effects on insulin secretion $O A$ also caused a significant decrease in total cellular insulin content, reducing it from $17608 \cdot 9 \pm 3816 \cdot 2$ to $10598 \cdot 9 \pm 3876 \cdot 1 \mathrm{ng}$ insulin/ $\mu \mathrm{g}$ DNA (Fig. 1B). 


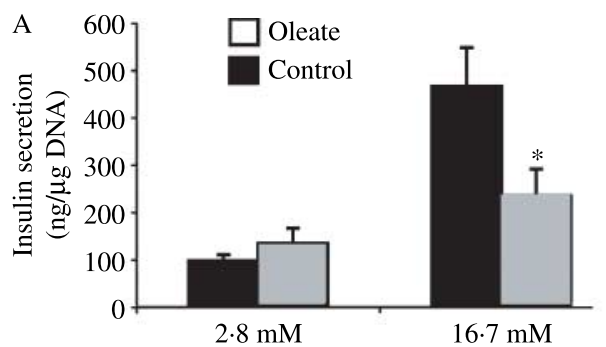

$\mathrm{C}$

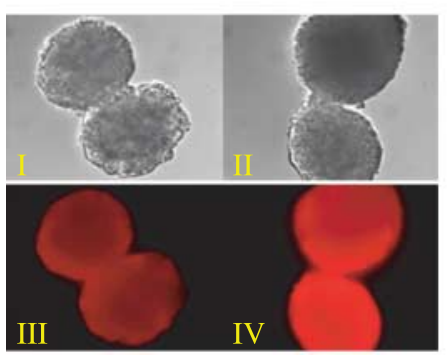

B
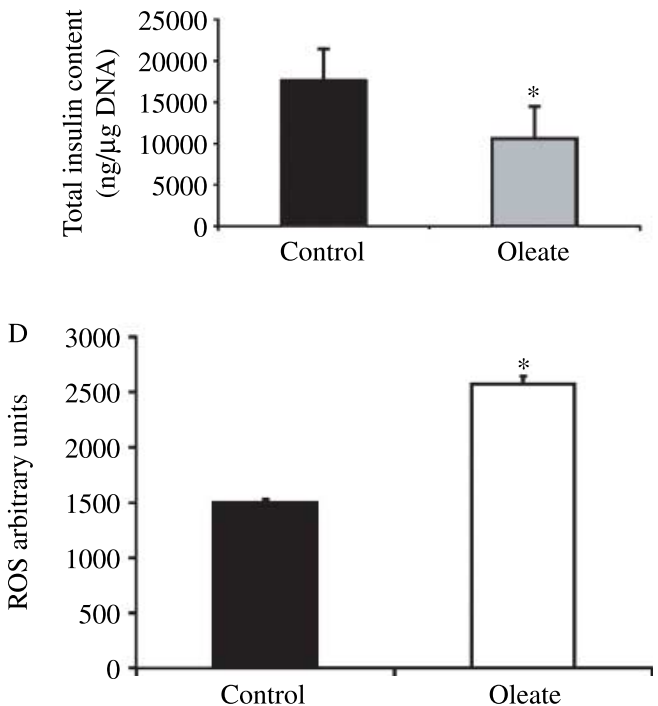

Figure 1 (A) The effect of 48 -h treatment of human pancreatic islets with oleate (OA $0 \cdot 4 \mathrm{mM}+0 \cdot 5 \%$ BSA) on basal $(2 \cdot 8 \mathrm{mmol} / \mathrm{l})$ and glucose-stimulated insulin secretion $(16 \cdot 7 \mathrm{mM}) .{ }^{*} P<0 \cdot 05$ for OA versus control (BSA) at $16.7 \mathrm{mmol} / \mathrm{l}$ glucose. Insulin secretion measurements were normalized to cellular DNA content. Results are the means of four separate experiments $(n=4)$. Black bars represent human islets treated with BSA only, while white bars indicate human islets treated with OA. (B) The effect of 48-h treatment of human pancreatic islets with OA $(0.4 \mathrm{mmol} / \mathrm{l})$ on total insulin content. For each experiment, 50 human islets were treated with $\mathrm{OA}$ or BSA and subsequently total insulin content was determined. ${ }^{*} P<0 \cdot 05$ for OA versus control (BSA). Total insulin content measurements were normalized to the cellular DNA content. Results are the means of four separate experiments $(n=4)$. (C) Microscopy images of human islets. Representative light microscopy images of human islets treated with: I) $\mathrm{BSA}$ and II) $0.4 \mathrm{mmol} / \mathrm{I} \mathrm{OA}$ for $48 \mathrm{~h}$. Fluorescent images (DCF fluorescence) of human islets treated with: III) BSA and IV) $0.4 \mathrm{mmol} / \mathrm{l}$ OA for $48 \mathrm{~h}$. (D) Quantification of fluorescence (ROS arbitrary units) in BSA- and OA-treated human islets. OA $(0.4 \mathrm{mmol} / \mathrm{l})$ was added to the DCF containing medium and the measurements were performed at $5.5 \mathrm{mmol} / \mathrm{l}$ glucose. Results are the means of three separate experiments performed in triplicate.

The effects of $\mathrm{OA}$ on global gene expression in human pancreatic islets

The changes in gene expression profiles were identified as being increased or decreased by comparing fatty acid treatment with BSA control. As shown in Fig. 3G, out of the 14500 genes or expressed sequence tags (ESTs) analyzed by gene microarray, OA decreased the expression of 601,561 , 139, 356, and 502 and increased the expression of 239, 100, 165, 194, and 968 genes or ESTs in five independent donor microarray analyses respectively. However, OA only altered the expression profiles of 40 genes consistently in five independent experiments. Out of these 40 genes, 27 were upregulated while 13 genes downregulated (Table 1). Table 1 shows the genes that were subsequently validated by means of real-time PCR. A total of 34 out of the $40(85 \%)$ genes deemed significantly changed by the microarray analysis were further confirmed by the real-time PCR.

\section{$\mathrm{O} A$ affected genes involved in metabolism}

The development of obesity and associated insulin resistance involves a multitude of gene products, including proteins involved in lipid synthesis and oxidation. Fatty acids have a very strong direct influence on the molecular events that govern transcription. In our study, the genes involved in metabolism comprised the largest functional cluster with 25\% (10 out of 40) classified in this category (Table 1). Treatment with OA resulted in the upregulation of enzymes involved in fatty acid $\beta$-oxidation such as acyl-coenzyme A dehydrogenase, very long chain $(2 \pm 0 \cdot 16$-fold); carnitine palmitoyltransferase 1 (CPT1; $3 \cdot 77 \pm 0 \cdot 71)$; acetyl-coenzyme A acyltransferase 2 $(1 \cdot 64 \pm 0 \cdot 15)$; enoyl-coenzyme A hydratase, $1(2 \cdot 1 \pm 0 \cdot 06)$; and mitochondrial trifunctional protein $(1 \cdot 72 \pm 0 \cdot 16)$. Finally, a great upregulation in angiopoietin-like protein 4 (over fourfold) was observed in both microarray analysis and $\mathrm{qPCR}$ validation. In order to further investigate the role of $\mathrm{OA}$ on $\beta$-oxidation, human islets were chronically treated with $\mathrm{OA}$ for $48 \mathrm{~h}$ as a model of chronic FFA exposure. Fatty acid oxidation was upregulated by $30 \%$ in islets treated with OA compared with BSA-treated control islets (Fig. 2A). This finding is in accordance with the human islet transcriptional profile demonstrating an upregulation of genes of fatty acid $\beta$-oxidation (Table 1). Additionally, as shown in Fig. 2B, OA pre-exposed islets showed a $75 \%$ reduction in their ability to 
Table 1 List of genes transcriptionally regulated by oleate $(\mathrm{OA})$ treatment in human islets of five individual donors

\section{Microarray}

\section{Gene}

Fatty acid/glucose metabolism

Acyl-coenzyme A dehydrogenase, very long chain (ACAVDL)

Monoglyceride lipase (MGLL)

Enoyl coenzyme A hydratase $1(\mathrm{ECH} 1)$

Carnitine palmitoyltransferase 1A, liver (CPT1A)

Mitochondrial trifunctional protein (HADHA)

Adipose differentiation-related protein (ADFP)

Acetyl-coenzyme A acyltransferase (ACAA2)

PPAR $\gamma$ angiopoietein-related protein (ANGPTL4)

Aldo-keto reductase, family 1 , member B10 (AKR1B10)

Methylcrotonoyl-coenzyme A carboxylase 1 (MCCC1)

Cellular transport

Aquaporin 3 (AQP3)

Glycolysis

Aldolase B

Cell proliferation

Insulin-induced gene 1 (INSIG1)

IGF-binding protein 3 (IGFBP3)

Electron transport

Cytochrome P450, family 1 , subfamily B, polypeptide 1

(CYP1B1)

Electron transfer flavoprotein, $\alpha$-polypeptide (ETFA)

Electron transfer flavoprotein, $\beta$-polypeptide (ETFB)

CGI-44 protein; sulfide dehydrogenase like (SQRDL)

Inflammatory response

C-reactive protein, pentraxin related (CRP)

Chemokine ligand 1, CX3CL1 (Fractalkine)

Tumor necrosis factor superfamily, member 21 (TNFRSF21)

Prostaglandin-endoperoxidase synthase 2 (PTGS2)

Oxidative stress

Catalase (CAT)

Metallothionein 1F (MTF1)

Sequestosome 1 (SQSTM1)

Signal transduction

Regulator of G-protein signaling 4 (RGS4)

Growth differentiation factor 15 (GDF15)

Neuromedin B (NMB)

Cytolysis

Monocyte to macrophage differentiation associated (MMD)

Regulation of transcription

Inhibitor of DNA binding 4 (ID4)

v-myc myelocytomatosis viral oncogene homolog (avian; MYC)

Cell motility

Vanin 1 (VNN1)

Cytoskeleton organization

Carobohydrate sulfotransferase 6 (CHST6)

Keratin 6B (KRT6B)

Cell cycle regulation

Transforming growth factor- $\alpha$ (TGFA)

Cell adhesion

Galectin-4 (LGALS4)

Transport

Transcobalamin 1 (TCN1)

Other

C10 open reading frame $10(\mathrm{C} 10$ orf10)

Phosphodiesterase 10A (PDE10A)

Glomerular epithelial protein 1 (GLEPP1)

Real-time PCR

$+1 \cdot 62 \pm 0 \cdot 11$

$+1 \cdot 26 \pm 0 \cdot 05$

$+1 \cdot 37 \pm 0 \cdot 08$

$+2 \cdot 2 \pm 0 \cdot 12$

$+1 \cdot 43 \pm 0.05$

$+3 \cdot 83 \pm 1 \cdot 09$

$+1.51 \pm 0.09$

$+4 \cdot 34 \pm 1 \cdot 10$

$+1 \cdot 31 \pm 0.05$

$-0 \cdot 80 \pm 0 \cdot 07$

$1 \cdot 26 \pm 0 \cdot 11$

$-0.69 \pm 0.06$

$-0 \cdot 76 \pm 0 \cdot 06$

$-0 \cdot 74 \pm 0 \cdot 11$

$-0 \cdot 79 \pm 0 \cdot 06$

$+1 \cdot 49 \pm 0.08$

$+1 \cdot 35 \pm 0 \cdot 10$

$+1 \cdot 28 \pm 0 \cdot 10$

$+1.35 \pm 0.09$

$+2 \cdot 08 \pm 0 \cdot 12$

$+1.51 \pm 0.09$

$-0 \cdot 85 \pm 0 \cdot 20$

$+1.43 \pm 0.05$

$+1 \cdot 19 \pm 0.09$

$+1 \cdot 41 \pm 0.08$

$-0 \cdot 65 \pm 0 \cdot 12$

$+1 \cdot 35 \pm 0 \cdot 16$

$-0.82 \pm 0.11$

$+1.55 \pm 0.07$

$-0 \cdot 76 \pm 0 \cdot 03$

$+1 \cdot 30 \pm 0 \cdot 10$

$-0 \cdot 89 \pm 0 \cdot 10$

$+1.37 \pm 0.09$

$+1 \cdot 69 \pm 0 \cdot 12$

$+1 \cdot 33 \pm 0 \cdot 03$

$+1 \cdot 55 \pm 0 \cdot 22$

$-0.68 \pm 0.08$

$-0 \cdot 79 \pm 0.04$

$+1 \cdot 55 \pm 0 \cdot 22$

$-0.82 \pm 0.08$
$+2 \pm 0 \cdot 16$

$+1 \cdot 27 \pm 0.08$

$+2 \cdot 1 \pm 0.06$

$+3 \cdot 77 \pm 0 \cdot 71$

$+1.72 \pm 0.16$

$\mathrm{NC}$

$+1 \cdot 63 \pm 0.15$

$+4 \cdot 1 \pm 0 \cdot 12$

$+1.76 \pm 0.17$

$-0 \cdot 75 \pm 0 \cdot 10$

NC

NC

$-0 \cdot 75 \pm 0 \cdot 19$

NC

NC

$+1 \cdot 32 \pm 0 \cdot 05$

$+1 \cdot 33 \pm 0.05$

$+1 \cdot 41 \pm 0.11$

$+1 \cdot 42 \pm 0.05$

$+2 \cdot 47 \pm 0 \cdot 11$

$+1.46 \pm 0.08$

$\mathrm{NC}$

$+1 \cdot 70 \pm 0 \cdot 10$

$+1 \cdot 49 \pm 0 \cdot 12$

$+1.47 \pm 0.08$

$-0.75 \pm 0 \cdot 19$

$+1.45 \pm 0.09$

$-0.82 \pm 0.06$

$+1 \cdot 59 \pm 0 \cdot 13$

$-0 \cdot 80 \pm 0 \cdot 09$

$+1 \cdot 54 \pm 0 \cdot 14$

$-0 \cdot 84 \pm 0 \cdot 10$

$+2 \cdot 13 \pm 0 \cdot 21$

$+1.95 \pm 0.10$

$+1 \cdot 64 \pm 0 \cdot 13$

$+1 \cdot 40 \pm 0 \cdot 11$

$-0 \cdot 67 \pm 0 \cdot 10$

$-0.74 \pm 0.06$

$+2 \cdot 56 \pm 0 \cdot 31$

$-0.82 \pm 0 \cdot 10$
Accession number

NM_000018

BC006230

NM_001398

NM_001031847

NM_000182

NM_001122

NM_006111

NM_139314

NM_020299

NM_020166

NM_004925

NM_000035

NM_005542

NM_000598

NM_000104

NM_000126

NM_001985

NM_021199

NM_000567

NM_002996

NM_014452

NM_000963

NM_001752

NM_005949

NM_003900

NM_005613

NM_004864

NM_021077

NM_012329

U16153

NM_002467

NM_004666

NM_021149

Al831452

NM_003236

NM_006149

NM_001062

NM_007021

NM_006661

U20489

Both microarray and real-time PCR analyses are shown for the genes of interest. NC, no change (indicates genes that were not validated by real-time PCR analysis). 

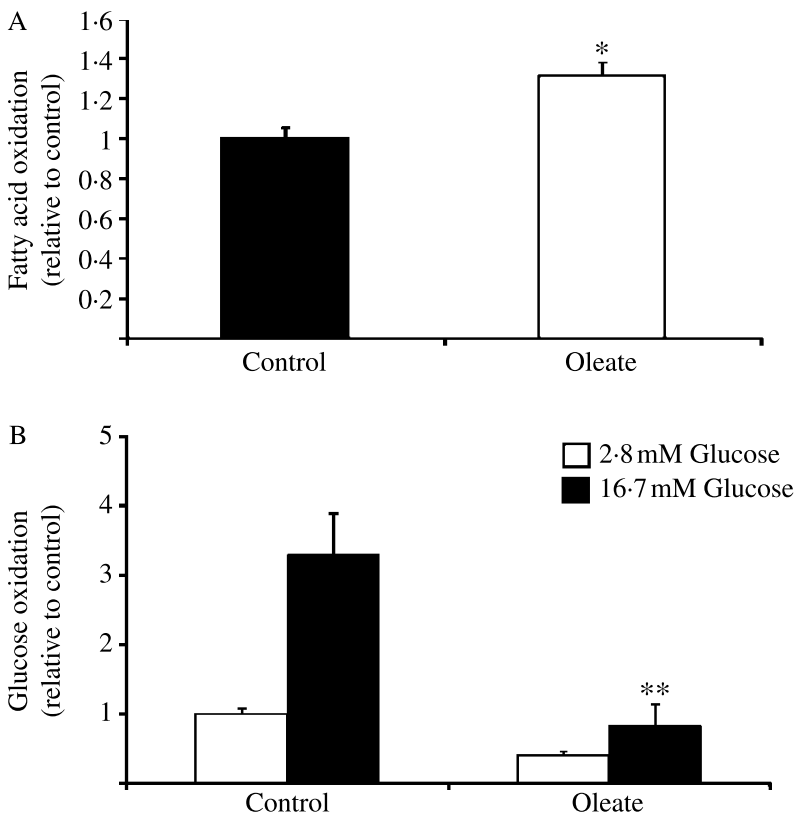

Figure 2 (A) Fatty acid oxidation in human pancreatic islets exposed for $48 \mathrm{~h}$ to $0 \cdot 4 \mathrm{mmol} / \mathrm{l}$ oleate. $\left[1-{ }^{14} \mathrm{C}\right]$ oleic acid was added at the end of the culture period. ${ }^{*} P<0 \cdot 05$ for OA versus control (BSA) at high glucose. (B) Glucose oxidation at 2.8 or $16.7 \mathrm{mmol} / \mathrm{l}$ glucose in human pancreatic islets cultured either with or without $0 \cdot 4 \mathrm{mmol} / \mathrm{l} \mathrm{OA}$ as indicated. ${ }^{* *} P<0 \cdot 01$ for $\mathrm{OA}$ versus control (BSA) at $16.7 \mathrm{mmol} / \mathrm{l}$ glucose.

oxidize glucose, whereas no changes were observed in glucose oxidation under basal conditions.

OA upregulated genes involved in inflammation, oxidative stress, and transcription

Whether there is a clear role for inflammation in the development of T2D at the level of the $\beta$ cell has not been ascertained. In our study, OA treatment upregulated the expression of genes involved in the generation of inflammation (Table 1) such as tumor necrosis factor receptor superfamily member $21(1 \cdot 47 \pm 0 \cdot 08)$, fractalkine (CX3CL1; $\cdot 47 \pm 0 \cdot 11)$, and C-reactive protein (CRP; $1 \cdot 42 \pm 0 \cdot 05)$. An upregulation of enzymes involved in oxidative stress/defense was also elicited by $\mathrm{OA}$ treatment with the induction of catalase $(1 \cdot 7 \pm 0 \cdot 1)$, metallothionein $1 \mathrm{~F}(1 \cdot 49 \pm 0 \cdot 12)$, and sequestosome $1(1 \cdot 47 \pm$ $0 \cdot 08)$. Interestingly, fatty acid treatment resulted in the upregulation of aldose reductase $(A K R 1 B 10 ; 1 \cdot 76 \pm 0 \cdot 17)$, an enzyme that has been implicated in the pathogenesis of T2D (Srivastava et al. 2005; Table 1). OA treatment resulted in the upregulation of $c M Y C(1.54 \pm 0 \cdot 14)$, a member of the $M Y C$ family of oncogenes that code for nuclear phosphoproteins that appear to promote cell growth and transformation by regulating the transcription of target genes required for proliferation (Table 1). Fatty acids have been implicated in the formation of ROS in many models of lipotoxicity. Furthermore, increased oxidative stress has been reported to be associated with the diabetic condition in several experimental and clinical settings (Robertson et al. 2004, Del Guerra et al. 2005).In the present study, we further explored the role of oxidative stress because oxidative markers were upregulated in our microarray analysis. The exposure of human islets to OA treatment $(0 \cdot 4 \mathrm{mmol} / \mathrm{l})$ for $48 \mathrm{~h}$ caused a significant increase in ROS production (approximately twofold, $P<0 \cdot 05$ ) as shown in Fig. $1 \mathrm{C}$ and D.

Effects of $\mathrm{O} A$ on glucose sensing, insulin signaling, and exocytosis

We used the real-time PCR to test for the involvement of chronic FFA exposure on the regulation of genes involved in glucose sensing, insulin signaling, fatty acid metabolism, mitochondrial function, transcription, and cell survival. Although these genes were not changed by microarray analysis, we used PCR, a more sensitive detection method that favors the detection of low-abundance genes. Supplemental Fig. 1, which can be viewed online at http://joe.endocrinology-journals. org/content/vol196/issue3/ shows the results demonstrating that OA treatment lead to an increase in the mRNA level for uncoupling protein 2 (UCP2). In addition, we observed a modest reduction in the level of GLUT2 mRNA $(0 \cdot 74 \pm 0 \cdot 22-$ fold), as well as a modest increase in the exocytotic SNARE protein syntaxin-4 $(1 \cdot 18 \pm 0 \cdot 24$-fold $)$ mRNA levels that were not statistically significant.

\section{Other genes unaffected by $O A$ treatment}

$\mathrm{T} 2 \mathrm{D}$ is attributed to various factors affecting $\beta$-cell function. The transcriptional regulation of mature onset diabetes of the young genes, pancreatic hormones, and glucose metabolism proteins was examined, as well as important islet transcription factors including the members of the family of bHLH/PAS transcription factors. Our findings revealed that OA treatment did not significantly change the mRNA levels of any of these genes (Supplemental Fig. 2, which can be viewed online at http://joe. endocrinology-journals.org/content/vol196/issue3/).

\section{GO annotation of gene expression among donor islets}

We compared the overlap among the lists of differentially expressed genes in all five donors (Fig. 3) using the L2L Microarray Analysis Tool (Seattle, WA, USA). There are subsets of genes that are highly regulated by FFA treatment in all five donors independently of the donor-specific parameters. These subsets include signal transducers, cell growth/cell survival regulators, metabolic regulators, and importantly, regulators of immune, inflammatory, and oxidative stress responses indicating significant similarities against fatty acid-induced changes in gene transcription.

\section{Discussion}

Most of the studies addressing the effects of fatty acids on $\beta$ cells have employed rat, mouse, or hamster-derived 
A

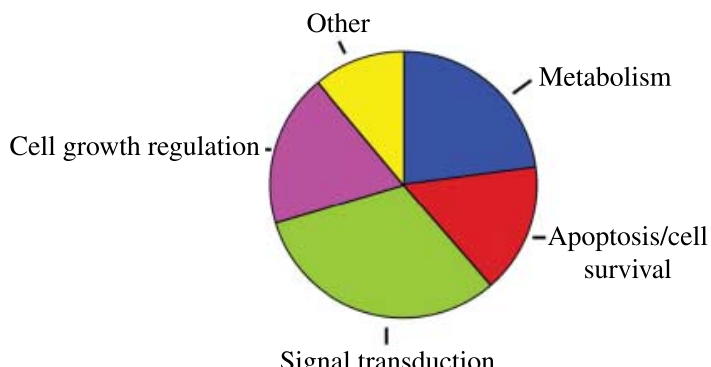

Signal transduction

$\mathrm{C}$

Immune response

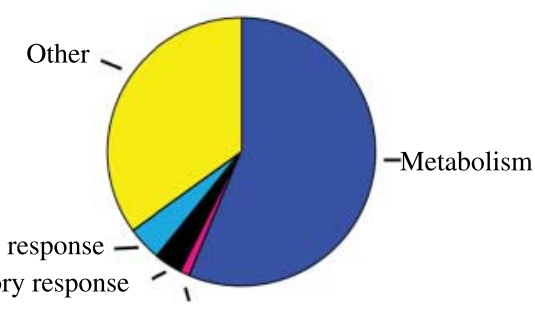

Cell growth regulation

$\mathrm{E}$

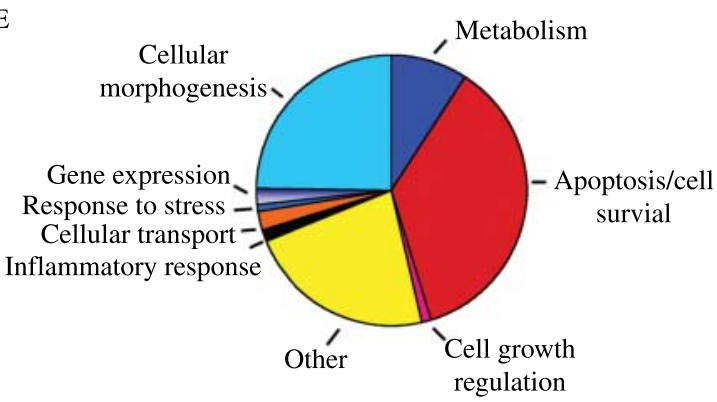

B

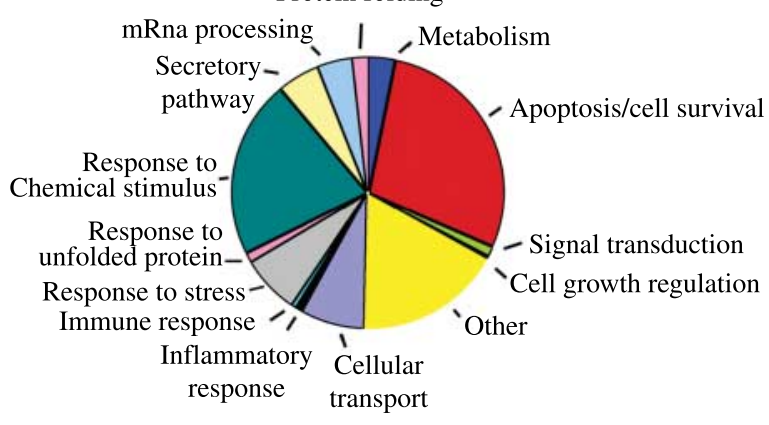

$\mathrm{D}$

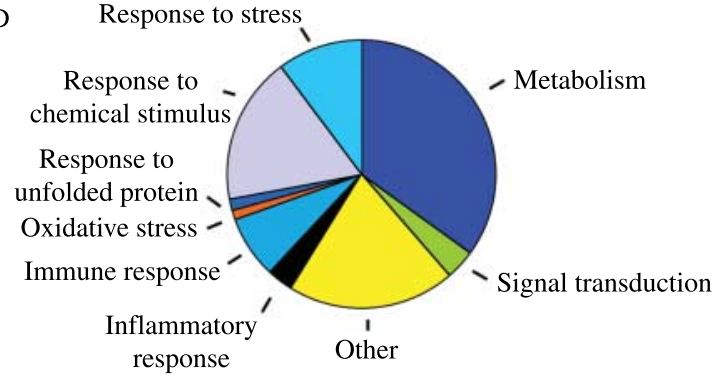

$\mathrm{F}$

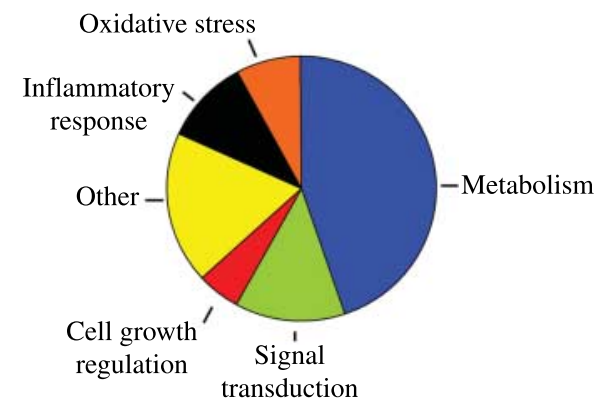

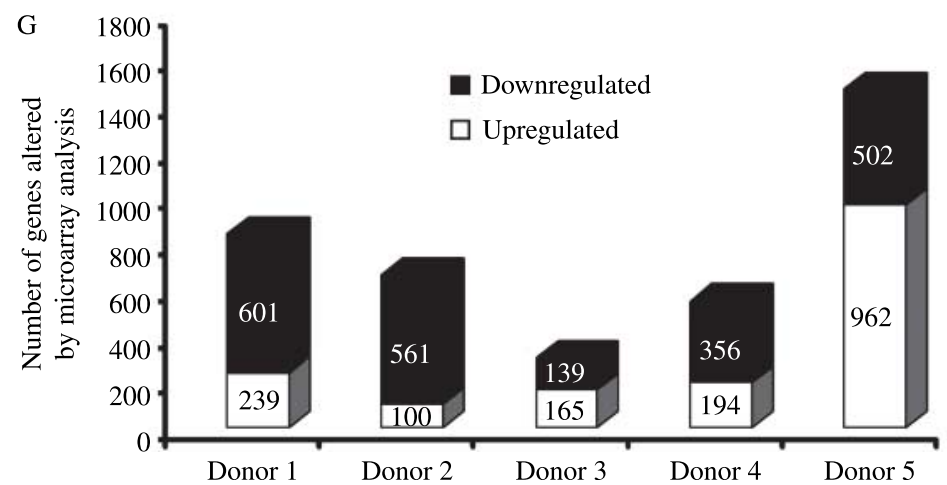

Figure 3 Genes transcriptionally regulated by OA. Clustering was based on their known biological function for all five donors examined. Results for each individual cluster are shown as percentages of the total genes deemed significantly altered by microarray analysis. The gene ontology analysis was performed using the L2L Microarray Analysis Tool (http://depts.washington.edu/l2l/), a database of published human microarray gene expression data, and a software tool for comparing the published data to a particular microarray results set. (A-E) Donors $1-5)$, (F) all five donors combined, and (G) number of genes or EST upregulated and downregulated following treatment with OA (0.4 mmol/l) for $48 \mathrm{~h}$ in five independent experiments. The Microarray Suite 5.0 (MAS5) method (Affymetrix)was used to obtain probe set summaries. 
insulinoma $\beta$-cell lines or islets for in vitro studies. Although the commonly used rodent $\beta$-cell lines have provided a wealth of information and valuable insights into $\beta$-cell function in normal and pathological states, controversies still exist about the effects of increased plasma FFA concentration on human $\beta$-cell function in vivo. In order to address this issue, we have used DNA microarray technology to study the effects of OA on human pancreatic islet physiology. We compared global gene profiles of control islets (exposed to BSA only) versus islets chronically exposed to OA. Here, we provide novel evidence that $\mathrm{OA}$ treatment of human islets regulates multiple gene networks involved in metabolism, apoptosis/cell survival, signal transduction, response to stress, response to inflammation, immunity, and ER stress.

T2D is primarily characterized by impaired insulin secretion and action. One of the early indications of the defect in insulin secretion is selective impairment in GSIS. The great majority of type 2 diabetic individuals are obese and often have elevated plasma levels of FFA (Boden 1997), which seems to be a consequence of their expanded (Bjorntorp et al. 1969) and more lipolytically active (Rebuffe-Scrive et al. 1990) adipose tissue. It is well established that FFA can impair insulin action (Delarue \& Magnan 2007) in peripheral tissues. However, it is less clear whether FFA can also impair $\beta$-cell function and play an important role in the defect in GSIS that characterizes T2D. OA and palmitate are the most abundant circulating fatty acids, representing 41 and $21 \%$ of the total amount of fatty acid circulating in the blood respectively (Richieri \& Kleinfeld 1995). Our results indicate that in human islets ex vivo, chronic exposure to OA causes selective loss of glucose responsiveness as shown by a marked reduction $(50 \%)$ in GSIS. These results are in line with other human islet ex vivo studies that reported decreased GSIS in human islets cultured for $48 \mathrm{~h}$ with either $0.125 \mathrm{mmol} / \mathrm{l}$ palmitate or OA (Zhou \& Grill 1995). Similar results were also reported by Lupi et al. (2002b) and Dubois et al. (2004) showing suppression of GSIS from human islets after exposure for $48 \mathrm{~h}$ to a $2 \mathrm{mmol} / \mathrm{l}$ mixture of $\mathrm{OA}$ and palmitate. Although the above studies clearly indicate the loss of glucose responsiveness as a result of FFA pre-exposure, they do not differentiate the effect of each FFA subtype, i.e., monounsaturated versus saturated. In addition, since the concentration of FFA in normal human plasma in vivo generally ranges between 0.1 and $0.5 \mathrm{mmol} / 1$ (Roden 2004), the majority of the aforementioned studies have used supraphysiological concentrations usually found in diabetic individuals. Our findings are unique since they are the first to investigate the effect of $\mathrm{OA}$ on human islet insulin secretion under physiological glucose concentrations in non-obese and non-diabetic donors. Pre-exposure to OA also reduced islet insulin content by $40 \%$ in accordance with the previously published results (Zhou \& Grill 1995, Wang et al. 2004). The reduction of insulin content by $\mathrm{OA}$ in our study did not occur at the level of transcription, since insulin mRNA levels were unchanged as assessed by microarray analysis. This raises the possibility that modulation of insulin content by OA may occur at the posttranscriptional level. Moreover, OA may also have translation-independent effects on insulin content by modulation of posttranslation pathways and/or degradation of insulin.

Fatty acid-induced derangements in GSIS involve a multitude of factors including: triglyceride accumulation (Muoio \& Newgard 2006), disruption of glucose metabolism (Shoelson et al. 2007), increased UCP2 expression (Joseph et al. 2002), mitochondrial fuel metabolism, and generation of secretion coupling factors via pyruvate cycling pathways (Newsholme et al. 2007a), increases in CPT1 expression (Xiao et al. 2001), increases in the level of ROS in $\beta$ cells (Koshkin et al. 2003, Oprescu et al. 2007), and most recently the GPR 40 receptor (a putative FFA receptor; Steneberg et al. 2005). In our study, we observed a significant upregulation of genes involved in the $\beta$-oxidation of FFA (see Table 1) including CPT1 $(\sim 2 \cdot 2$-fold), which is in accordance with the previous studies (Dubois et al. 2004). CPT1 represents a rate-limiting step for the import of long-chain fatty acids (LCFAs) into the mitochondria for $\beta$-oxidation. Activation of CPT1 may be seen either as a positive (McGarry \& Dobbins 1999, Unger \& Zhou 2001) or negative (Randle et al. 1963, Roduit et al. 2004) phenomenon for pancreatic $\beta$-cell function. When activated, CPT1 facilitates oxidation of LCFAs, which could prevent their accumulation as longchain fatty acyl-CoA or other lipid metabolites in the cytosol and exert an antilipotoxic effect in $\beta$ cells (Unger \& Zhou 2001). Alternatively, increased oxidation of LCFAs by CPT1 activation could lead to the impairment of glucose metabolism through substrate competition, as postulated previously by the glucose-fatty acid cycle (Randle et al. 1963), and affect the ability of $\beta$ cells to sense glucose and secrete insulin. Interestingly, in our experiments, OA oxidation was significantly increased $(\sim 30 \%)$ after exposure of human pancreatic islets to this fatty acid for $48 \mathrm{~h}$. Even though this may have contributed to minimize the lipotoxic effect induced by chronic exposure to $\mathrm{OA}$, it was not sufficient to prevent the impairment of GSIS induced by this fatty acid. In this context, it is important to consider that glucose is the most potent nutrient secretagogue for pancreatic $\beta$ cells and its metabolism is essential for coupling to occur between glucose sensing and release of insulin by $\beta$ cells (Roduit et al. 2004). It is widely accepted that an increase in the cytosolic ATP-to-ADP ratio, as a result of glucose metabolism, is an important event in this process. An increase in this ratio closes ATP-sensitive $\mathrm{K}^{+}$channels, causing depolarization of the plasma membrane. This, in turn, opens voltage-gated $\mathrm{Ca}^{2+}$ channels, causing influx of $\mathrm{Ca}^{2+}$ and exocytosis of insulin secretory granules (MacDonald et al. 2005). Previous studies have shown that lipotoxicity in human islets leads to selective loss of glucose responsiveness with no effect on insulin secretion in response to arginine (Lupi et al. 2002a). This suggests that FFA selectively impair the release of insulin mediated by glucose, possibly by interfering with its metabolism. In our study, we tested this hypothesis by measuring glucose oxidation in islets 
pre-exposed to OA. We observed a marked reduction in the ability of islets to oxidize glucose at low $(2.8 \mathrm{~mol} / \mathrm{l})$ and high $(16.7 \mathrm{mmol} / \mathrm{l})$ concentrations of this substrate, which is compatible with the inhibition of GSIS induced by OA. Our findings support the hypothesis that OA-induced inhibition of GSIS may be related, at least in part, to impaired glucose metabolism by substrate competition, which is a plausible mechanism by which OA caused the suppression of GSIS in our study.

There is also compelling evidence that an increase in UCP2 expression results in the suppression of GSIS, whereas the absence of UCP2 enhances GSIS (Chan et al. 2004). Upregulation of UCP2 expression inhibits ATP synthesis. FFA have been shown to increase UCP2 mRNA and protein levels in $\beta$ cells. As a result, ATP synthesis is reduced and GSIS is blunted (Zhang et al. 2001). Furthermore, UCP2 knockout mice have lower fasting glucose levels and elevated circulating insulin levels when fed a high-fat diet compared with wildtype littermates (Joseph et al. 2002). Exposure of wild-type mouse islets to palmitate reduces GSIS, whereas UCP2 $2^{-1-}$ islets show enhanced GSIS (Chan et al. 2004). Our study demonstrated an increase in mRNA levels of UCP2 in human islets following OA treatment by means of real-time PCR, which is consistent with the notion that UCP2 negatively correlates with GSIS.

Oxidative stress has been shown to decrease GSIS induced by prolonged exposure to fatty acids and glucose (Oprescu et al. 2007, Tang et al. 2007). The inability of $\beta$ cells to respond to a glucose challenge in the presence of ROS might represent an adaptive response (also known as lipoadaptation) in an attempt to further limit ROS generation, thereby allowing the $\beta$ cell to resist apoptosis. Here, we demonstrate for the first time a stimulatory effect of OA on ROS production in human islets, a finding that is in line with the previously published studies (Carlsson et al. 1999, Oprescu et al. 2007). Additionally, increased ROS may represent a potential source of pancreatic $\beta$-cell deregulation, given the low expression of antioxidant enzymes in islets (Robertson et al. 2005).

Several lines of evidence have established a link between inflammation and the development of obesity and T2D (Wellen \& Hotamisligil 2005). In our analysis, several genes implicated in the generation of inflammation were upregulated. These include tumor necrosis factor receptor, fractalkine, and CRP suggesting that fatty acids could act via this pathway to accelerate deterioration of $\beta$-cell function. Additionally, one important study implicates fatty acids in the induction of inflammation using microarray analysis in the murine pancreatic $\beta$-cell line MIN6 (Busch et al. 2002). This study clearly demonstrates that palmitate and OA lead to an upregulation of transcripts involved in the inflammatory response with the former eliciting a more pronounced response than the latter.

In summary, our study of human islets chronically exposed to OA recapitulated some of the functional abnormalities observed in patients with T2D. These include: an impairment of GSIS, a reduction of total insulin content, and elevated production of ROS. In addition, our study is the first to demonstrate a direct mechanism by which elevated FFA diminish GSIS in human islets. This mechanism entails increased FFA oxidation with a concomitant decrease in glucose oxidation. Finally, our results also suggest that chronic exposure to FFA treatment of human islets mediates alterations in genes implicated in inflammation and immunity. Taken together, our findings have identified several candidate molecules for further investigation into the mechanism of lipotoxicity in human pancreatic islets.

\section{Acknowledgements}

This work was supported by operating grants from the Canadian Diabetes Association (CDA) and the Canadian Institutes of Health Research (MOP 12898) to M B W. Also, M B W is supported by a CIHR Investigator Award, M R A by a CIHR Scientist award, R B C by operating grants from CDA and CIHR, G B by an NSERC trainee award and by a Banting and Best Diabetes Centre-Novo Nordisk Studentship, S C L by a Banting and Best Diabetes Centre-Novo Nordisk Studentship, and A S P by a post-doctoral fellowship from the Brazilian Ministry of Education (CAPES). The authors declare that there is no conflict of interest that would prejudice the impartiality of this scientific work.

\section{References}

Bjorntorp P, Bergman H, Varnauskas E \& Lindholm B 1969 Lipid mobilization in relation to body composition in man. Metabolism 18 840-851.

Boden G 1997 Role of fatty acids in the pathogenesis of insulin resistance and NIDDM. Diabetes 46 3-10.

Busch AK, Cordery D, Denyer GS \& Biden TJ 2002 Expression profiling of palmitate- and oleate-regulated genes provides novel insights into the effects of chronic lipid exposure on pancreatic beta-cell function. Diabetes $\mathbf{5 1}$ 977-987.

Carlsson C, Borg LA \& Welsh N 1999 Sodium palmitate induces partial mitochondrial uncoupling and reactive oxygen species in rat pancreatic islets in vitro. Endocrinology 140 3422-3428.

Chan CB, Saleh MC, Koshkin V \& Wheeler MB 2004 Uncoupling protein 2 and islet function. Diabetes $\mathbf{5 3}$ (Suppl 1) S136-S142.

Delarue J \& Magnan C 2007 Free fatty acids and insulin resistance. Current Opinion in Clinical Nutrition and Metabolic Care 10 142-148.

Dubois M, Kerr-Conte J, Gmyr V, Bouckenooghe T, Muharram G, d'Herbomez M, Martin-Ponthieu A, Vantyghem MC, Vandewalle B \& Pattou F 2004 Non-esterified fatty acids are deleterious for human pancreatic islet function at physiological glucose concentration. Diabetologia 47 463-469.

Gaidhu MP, Fediuc S \& Ceddia RB 2006 5-Aminoimid, dazole-4carboxamide-1-beta-D-ribofuranoside-induced AMP-activated protein kinase phosphorylation inhibits basal and insulin-stimulated glucose uptake, lipid synthesis, and fatty acid oxidation in isolated rat adipocytes. Journal of Biological Chemistry 281 25956-25964.

Del Guerra S, Lupi R, Marselli L, Masini M, Bugliani M, Sbrana S, Torri S, Pollera M, Boggi U, Mosca F et al. 2005 Functional and molecular defects of pancreatic islets in human type 2 diabetes. Diabetes 54 727-735.

Haber EP, Ximenes HM, Procopio J, Carvalho CR, Curi R \& Carpinelli AR 2003 Pleiotropic effects of fatty acids on pancreatic beta-cells. Journal of Cell Physiology 194 1-12. 
Haber EP, Procopio J, Carvalho CR, Carpinelli AR, Newsholme P \& Curi R 2006 New insights into fatty acid modulation of pancreatic beta-cell function. International Review of Cytology 248 1-41.

Haslam DW \& James WP 2005 Obesity. Lancet 366 1197-1209.

Joseph JW, Koshkin V, Zhang CY, Wang J, Lowell BB, Chan CB \& Wheeler MB 2002 Uncoupling protein 2 knockout mice have enhanced insulin secretory capacity after a high-fat diet. Diabetes $\mathbf{5 1} 3211-3219$.

Koshkin V, Wang X, Scherer PE, Chan CB \& Wheeler MB 2003 Mitochondrial functional state in clonal pancreatic beta-cells exposed to free fatty acids. Journal of Biological Chemistry 278 19709-19715.

Koulouridis E 2004 Insulin and human obesity. Pediatric Endocrinology Reviews 1 (Suppl 3) 438-442.

Lupi R, Del Guerra S, Fierabracci V, Marselli L, Novelli M, Patane G, Boggi U, Mosca F, Piro S, Del Prato S et al. 2002a Lipotoxicity in human pancreatic islets and the protective effect of metformin. Diabetes $\mathbf{5 1}$ (Suppl 1) S134-S137.

Lupi R, Dotta F, Marselli L, Del Guerra S, Masini M, Santangelo C, Patane G, Boggi U, Piro S, Anello M et al. $2002 b$ Prolonged exposure to free fatty acids has cytostatic and pro-apoptotic effects on human pancreatic islets: evidence that beta-cell death is caspase mediated, partially dependent on ceramide pathway, and Bcl-2 regulated. Diabetes 51 1437-1442.

MacDonald PE, Joseph JW \& Rorsman P 2005 Glucose-sensing mechanisms in pancreatic beta-cells. Philosophical Transactions of the Royal Society of London. Series B: Biological Sciences 360 2211-2225.

Mason TM, Goh T, Tchipashvili V, Sandhu H, Gupta N, Lewis GF \& Giacca A 1999 Prolonged elevation of plasma free fatty acids desensitizes the insulin secretory response to glucose in vivo in rats. Diabetes 48 524-530.

McGarry JD \& Dobbins RL 1999 Fatty acids, lipotoxicity and insulin secretion. Diabetologia 42 128-138.

Muoio DM \& Newgard CB 2006 Obesity-related derangements in metabolic regulation. Annual Review of Biochemistry 75 367-401.

Newsholme P, Haber E, Hirabara S, Rebelato E, Propcopio J, Morgan D, Oliveira-Emilio H, Carpinelli A \& Curi R 2007a Diabetes associated cell stress and dysfunction - role of mitochondrial and non-mitochondrial ROS production and activity. Journal of Physiology 583 9-24.

Newsholme P, Keane D, Welters HJ \& Morgan NG 2007b Life and death decisions of the pancreatic beta-cell: the role of fatty acids. Clinical Science 112 27-42.

O'Gorman D, Kin T, Murdoch T, Richer B, McGhee-Wilson D, Ryan EA, Shapiro JA \& Lakey JR 2005 The standardization of pancreatic donors for islet isolations. Transplantation $\mathbf{8 0} 801-806$.

Oprescu AI, Bikopoulos G, Naassan A, Allister EM, Tang C, Park E, Uchino H, Lewis GF, Fantus IG, Rozakis-Adcock M et al. 2007 Free fatty acid-induced reduction in glucose stimulated insulin secretion evidence for a role of oxidative stress in vitro and in vivo. Diabetes 56 2927-2937.

Paolisso G, Gambardella A, Amato L, Tortoriello R, D'Amore A, Varricchio M \& D'Onofrio F 1995 Opposite effects of short- and long-term fatty acid infusion on insulin secretion in healthy subjects. Diabetologia 38 1295-1299.

Patane G, Piro S, Rabuazzo AM, Anello M, Vigneri R \& Purrello F 2000 Metformin restores insulin secretion altered by chronic exposure to free fatty acids or high glucose: a direct metformin effect on pancreatic betacells. Diabetes 49 735-740.

Randle PJ, Garland PB, Hales CN \& Newsholme EA 1963 The glucose fattyacid cycle. Its role in insulin sensitivity and the metabolic disturbances of diabetes mellitus. Lancet 1 785-789.

Rebuffe-Scrive M, Anderson B, Olbe L \& Bjorntorp P 1990 Metabolism of adipose tissue in intraabdominal depots in severely obese men and women. Metabolism 39 1021-1025.
Richieri GV \& Kleinfeld AM 1995 Unbound free fatty acid levels in human serum. Journal of Lipid Research 36 229-240.

Robertson RP, Harmon J, Tran PO \& Poitout V 2004 Beta-cell glucose toxicity, lipotoxicity, and chronic oxidative stress in type 2 diabetes. Diabetes 53 (Suppl 1) S119-S124.

Robertson RP, Tanaka Y, Takahashi H, Tran PO \& Harmon JS 2005 Prevention of oxidative stress by adenoviral overexpression of glutathionerelated enzymes in pancreatic islets. Annals of the New Academy of Sciences $1043513-520$

Roden M 2004 How free fatty acids inhibit glucose utilization in human skeletal muscle. News in Physiological Sciences 19 92-96.

Roduit R, Nolan C, Alarcon C, Moore P, Barbeau A, Delghingaro-Augusto V, Przybykowski E, Morin J, Masse F, Massie B et al. 2004 A role for the malonyl-CoA/long-chain acyl-CoA pathway of lipid signaling in the regulation of insulin secretion in response to both fuel and nonfuel stimuli. Diabetes 53 1007-1019.

Shoelson SE, Herrero L \& Naaz A 2007 Obesity, inflammation, and insulin resistance. Gastroenterology 132 2169-2180.

Srivastava SK, Ramana KV \& Bhatnagar A 2005 Role of aldose reductase and oxidative damage in diabetes and the consequent potential for therapeutic options. Endocrine Reviews 26 380-392.

Steneberg P, Rubins N, Bartoov-Shifman R, Walker MD \& Edlund H 2005 The FFA receptor GPR 40 links hyperinsulinemia, hepatic steatosis, and impaired glucose homeostasis in mouse. Cell Metabolism 1 245-258.

Stoughton RB 2005 Applications of DNA microarrays in biology. Annual Review of Biochemistry 74 53-82.

Stumvoll M, Goldstein BJ \& van Haeften TW 2005 Type 2 diabetes: principles of pathogenesis and therapy. Lancet 365 1333-1346.

Tang C, Han P, Oprescu AI, Lee SC, Gyulkhandanyan AV, Chan GN, Wheeler MB \& Giacca A 2007 Evidence for a role of superoxide generation in glucose-induced beta-cell dysfunction in vivo. Diabetes 56 2722-2731.

Unger RH \& Zhou YT 2001 Lipotoxicity of beta-cells in obesity and in other causes of fatty acid spillover. Diabetes $\mathbf{5 0}$ (Suppl 1) S118-S121.

Wang X, Li H, De Leo D, Guo W, Koshkin V, Fantus IG, Giacca A, Chan CB, Der S \& Wheeler MB 2004 Gene and protein kinase expression profiling of reactive oxygen species-associated lipotoxicity in the pancreatic beta-cell line MIN6. Diabetes 53 129-140.

Wellen KE \& Hotamisligil GS 2005 Inflammation, stress, and diabetes. Journal of Clinical Invesigation 115 1111-1119.

Xiao J, Gregersen S, Kruhoffer M, Pedersen SB, Orntoft TF \& Hermansen K 2001 The effect of chronic exposure to fatty acids on gene expression in clonal insulin-producing cells: studies using high density oligonucleotide microarray. Endocrinology 142 4777-4784.

Zhang CY, Baffy G, Perret P, Krauss S, Peroni O, Grujic D, Hagen T, VidalPuig AJ, Boss O, Kim YB et al. 2001 Uncoupling protein-2 negatively regulates insulin secretion and is a major link between obesity, beta cell dysfunction, and type 2 diabetes. Cell 105 745-755.

Zhou YP \& Grill V 1995 Long term exposure to fatty acids and ketones inhibits B-cell functions in human pancreatic islets of Langerhans. Journal of Clinical Endocrinology and Metabolism 80 1584-1590.

Received in final form 30 November 2007

Accepted 5 December 2007

Made available online as an Accepted Preprint 5 December 2007 